\title{
Palace coup may lift status of Biosphere 2
}

Washington. Dramatic events at the giant hermetically sealed greenhouse known as Biosphere 2 in the Arizona desert could lead to enhanced scientific credibility for the controversial facility, according to scientists close to the project.

Two weeks ago, Ed Bass, a Texan billionaire who has provided the financial backing for the $\$ 150$ million project, sacked the entire management team, led by Margret Augustine and John Allen, which conceived Biosphere 2 in 1984 and have run it ever since.

Bass issued a statement saying that the team had failed to implement sound financial controls and business practices. But it has also emerged that Bass was recently advised by scientists who have worked with Biosphere 2 that it could work better - and possibly attract federal funding - if it adopted a more focused scientific programme.

The sudden departure of Augustine, Allen and other 'true believers' in the project, if upheld by the courts, leaves the future of the facility wide open. The recent chain of events has brought the project's credibility to an all-time low. But some biologists think the departure of the founding individuals could help the facility to realize its full potential.

The 3-acre greenhouse is described as the largest closed ecological system in the world. Much of the early work carried out in Biosphere 2 has been derided by the scientific community for its lack of rigour. But the facility itself is seen as having great potential for the investigation of key ecological questions, such as the interaction between plants and carbon dioxide.

Wallace Broecker, a geochemist at the Lamont-Doherty Earth Observatory in New York State, says that a number of scientists who have worked with Biosphere 2 feel it could be made into a good facility. "It should

\section{Protest march targets French reactor}

Paris. Chanting "unplug Superphénix", about a thousand people set off last weekend from Creys-Malville, the site in southern France of the fast breeder reactor, on a four-week march that may herald the rebirth of the antinuclear movement in France.

Opposition in France to nuclear power has been muted in recent years, compared, for example, with the mid-1970s when a demonstrator was killed at Creys-Malville during running battles between the police and more than 20,000 protesters.

One reason is that opponents have been denied targets likely to rouse popular support. The government shut down Superphénix in 1987 following repeated leaks in its sodium cooling circuits, and be converted to focus on the study of carbon dioxide and plants," he says.

"They need a much more disciplined approach," says Broecker. He suggests that Biosphere should commission leading out-

\section{IMAGE UNAVAILABLE FOR COPYRIGHT REASONS}

Happier times: Abigail Alling, a former inhabitant now

side scientists to produce a new research plan. Broecker thinks that it would then be in a position to attract funding from government agencies, as well as to increase its attraction to tourists. Similar views were recently conveyed in some detail to Bass, although their effect is unknown.

As chairman of Space Biospheres Ventures (SBV) - the company that owns Biosphere 2 - Bass has taken court action in Texas to dissolve a joint venture with a company based in Oracle, Arizona, and headed by Augustine and Allen, that operates the facility.

Pending completion of the action, the court has granted an injunction barring $\mathrm{Au}$ gustine, Allen and four senior colleagues from the site, and has appointed a temporary receiver, Martin Bowen, to run Biosphere 2.

The anger provoked by Bass's action became clear when two more staff members suspended by Bowen - former Biosphere inhabitants Abigail Alling and Mark Van

imposed a 15-year moratorium on the deepstorage of nuclear waste in 1991.

But Greenpeace and other environmental organizations have now seized the opportunity presented by the government's recent decision to restart Superphénix to use the reactor as a rallying symbol. The greens' main goal is to influence France's first national debate on future energy strategies, which will take place next month in the National Assembly.

The protest march will end on 8 May at Matignon, the prime minister's office, after stopping off at various nuclear plants on the way to Paris and commemorating the eighth anniversary of the Chernobyl meltdown on 26 April.

Declan Butler
Thillo - allegedly smashed five air seals on Biosphere 2 and opened some of its doors.

Alling and Van Thillo announced publicly that they had done this in order to safeguard people working inside Biosphere 2. But both were subsequently arrested and charged with burglary, trespass and causing criminal damage.

Chris Helms, a spokesman for SBV, says that Biosphere 2 will function as usual under Bowen's management until the case, due to be heard by a court in Fort Worth on 19 May, is resolved.

Meanwhile, the research director, Jack Corliss, maintains that Biosphere 2 is continuing as a serious scientific project. "This is a change of management," he says. "It is not going to effect the evolution of Biosphere 2 into a top-notch research facility."

Corliss says that the break-in at Biosphere 2 resulted in the loss of about 15 per cent of the air inside the facility. But he claims it will not damage experiments because the nature of the change has been closely monitored.

Corliss also says he has not been asked to leave, and has no plans to resign. But some outside scientists are already speculating that Corliss's departure might be part of any effort to put the project on a new scientific footing.

Further evidence of turmoil at Biosphere 2 emerged last Friday when Norberto Alvarez-Romo, mission control manager and a member of a team of seven working inside the enclosed facility, was replaced by another manager.

A statement said Alvarez-Romo had left Biosphere 2 for a "family emergency", and to play a key role in mission restructuring". The statement contained no comment from Alvarez-Romo; previous statements from SBV had said that all of the crew had agreed to stay inside the facility.

In the longer term, Bass faces three main options if he wishes to cut his losses at Biosphere 2. The first is outright closure, which would write off almost all of his investment. Helms says categorically that the facility will not be shut down.

The second option is to make the venture more brazenly commercial, opening it as a kind of theme park. The third is to bolster the project's credibility by reintroducing a proper structure for the organization and peer review of science at the facility.

Helms says it is too early to comment on these options, but admits that restoration of a panel of outside advisers - the last one resigned en bloc last year, when it was not consulted on Corliss's appointment -- is "possible". 